\title{
History of Bermudagrass Turfgrass Breeding Research in Tifton, GA
}

\author{
Lisa L. Baxter and Brian M. Schwartz ${ }^{1}$ \\ Department of Crop and Soil Sciences, University of Georgia, Tifton Campus, 2360 Rainwater Road, Tifton, \\ GA 31793 \\ Additional index words. Cynodon dactylon, Cynodon transvaalensis, Tifton, Georgia, history
}

\begin{abstract}
Bermudagrass (Cynodon spp.) is the foundation of the turfgrass industry in most tropical and warm-temperate regions. Development of bermudagrass as a turfgrass began in the early 1900s. Many of the cultivars commercially available today have been cooperatively released by the U.S. Department of Agriculture Agricultural Research Service (USDA-ARS) and the University of Georgia at the Coastal Plain Experiment Station in Tifton, GA.
\end{abstract}

\section{The Beginning of a Legacy}

In 1946, Glen Burton and the USDA-ARS initiated a turfgrass breeding program in Tifton, GA to develop better bermudagrasses to replace sand putting greens or seeded varieties (Burton, 1991). Researchers scouted golf courses throughout the southeastern United States and collected accessions from the best turf-type bermudagrasses to be increased in a greenhouse and planted in field plots. These accessions were then crossed with common bermudagrass [Cynodon dactylon (ecotype: Tifton, GA); $2 n=4 x=36$ ]. The resulting progeny were subjected to standard golf green management practices before the best $F_{1}$ hybrid was selected for greater density, less weed presence, and greater disease resistance than the common ecotype (Burton, 1991; Hein, 1953). This tetraploid hybrid $(2 n=4 x=36)$ was released as Tifton 57 in 1952 and later commercially named 'Tiflawn' (Burton, 1991).

Although 'Tiflawn' showed improvement over existing bermudagrass cultivars, it was taller and coarser than desired (Burton, 1991). Cynodon transvaalensis $(2 n=2 x=$ 18 ) accessions from South Africa typically have fine leaves and made better putting surfaces than $C$. dactylon, but were very susceptible to diseases (Burton, 1991; Hein, 1953). 'Tiflawn' was crossed with $C$. transvaalensis and a superior genotype with finer, softer leaves and greater disease tolerance than the parent lines was selected (Burton, 1955; Hein, 1953; Robinson and Burton, 1953). This turfgrass was released as Tifton 127 and commercially named 'Tiffine' in 1953 for athletic fields and school playgrounds (Burton, 1991). This was the first vegetatively propagated, triploid hybrid $(2 n=$ $3 x=27$ ) released from the cooperative turfgrass breeding program in Georgia.

Next, researchers aimed to improve the putting surface of bermudagrass by making

Received for publication 30 May 2018. Accepted for publication 10 July 2018 .

'Corresponding author. E-mail: tifturf@uga.edu. This is an open access article distributed under the CC BY-NC-ND license (http://creativecommons. org/licenses/by-nc-nd/4.0/). hybrids between a $C$. dactylon selected from the fourth green of the Charlotte Country Club (Charlotte, NC) and C. transvaalensis (Burton, 1991; Hein, 1961). The best of these sterile triploid hybrids was released as Tifton 328 in 1956 and commercially named 'Tifgreen' (Burton, 1991). 'Tifgreen' was a popular choice for putting surfaces worldwide, as it was fine-textured with soft, forest green leaves and few seedheads (Burton, 1964, 1991).

An unintended triploid hybrid of $C$. transvaalensis and $C$. dactylon, discovered in 1954, was released as Tifton 419 and commercially released as 'Tifway' in 1960 (Burton, 1966a). The female parent was that of a C. transvaalensis seed lot provided by D. Meredith from South Africa (Burton, 1966a). Since 'Tifway' was triploid, the male parent was presumed to have been $C$. dactylon (Burton, 1966a). This hybrid was darker green than 'Tifgreen' and exhibited greater frost tolerance, disease and insect resistance, and wear tolerance (Burton, 1991). The denser, weed-free sod with greater leaf stiffness was coveted for tees and fairways. 'Tifway' has since become the standard to compare against when developing new turf bermudagrass cultivars, because of its widespread use and adaptation in the United States and across the globe (Hanna et al., 2013).

'Tifdwarf' was a chance somatic mutation of 'Tifgreen', officially released in 1965 (Burton, 1991). This dwarf bermudagrass was found occupying a $45-\mathrm{cm}$ diameter area on a golf green at the Country Club in Florence, SC, by U.S. Golf Association Green Section agronomist James B. (Monty) Moncrief (Burton, 1966b). T. M. Baumgardner and $\mathrm{M}$. McKendree found a similar area on a golf green at the Sea Island Country Club in Sea Island, GA. Both greens were planted with 'Tifgreen' in an experiment before its commercial release (Burton, 1966b, 1991). Plugs from both golf courses were brought to Tifton, increased, and evaluated with other bermudagrasses (Burton, 1991). It was concluded that 'Tifdwarf' was a natural mutant of 'Tifgreen' that had occurred in Tifton before the sprigs were distributed to golf courses for preliminary evaluations (Burton, 1966b, 1991). Although 'Tifdwarf' was similar to 'Tifgreen', it possessed shorter leaves, stems, internodes, and stolons (Burton, 1966b). It was slow to establish but better tolerated golf-green maintenance, which allowed it to spread at the Florence and Sea Island Country Clubs (Burton 1966b, 1991).

\section{Generating Variation from Radiation}

In 1970, the use of gamma rays from a cobalt- 60 source to induce mutations in sterile triploid hybrids began as these lines could not be improved by conventional breeding methods (Burton, 1991). Dormant bermudagrass sprigs from 'Tifway', 'Tifgreen', and 'Tifdwarf' were exposed to 7000 to 9000 rads of radiation to create 158 new mutants (Burton, 1991). 'Tifway II' and 'Tifgreen II' resulted from this initial experiment and were released in 1981 and 1983 , respectively (Burton, 1981, 1991). Even though 'Tifway II' was visually similar to Tifway, it was reported to be more resistant to root knot (Meloidogyne spp.), ring (Mesocriconema ornatum Raski), and sting (Belonolaimus longicaudatus $\mathrm{Rau}$ ) nematodes, more frost tolerant, and broke dormancy earlier in the spring (Burton, 1991). It produced a denser sod with fewer weeds, hypothetically making 'Tifway II' a better choice for lawns, fairways, and football fields (Burton, 1981). Despite this, the use of 'Tifway II' was relatively limited compared with 'Tifway'. 'Tifgreen II' was coarser than 'Tifgreen' and made a less-desirable putting surface due to heavy seedhead production, but it was lighter green and exhibited greater cold tolerance, required less maintenance, and recovered better each spring (Burton, 1981).

\section{Improving Winterhardiness}

Following the release of 'Tifgreen II', the Tifton Turfgrass Breeding Program created a new goal, to develop higher-quality, more winter-hardy bermudagrasses (Burton, 1991). In 1974, a hexaploid bermudagrass collection from a lawn in Shanghai, China, was introduced into the program because of its dark bluish-green color, winterhardiness, salt tolerance, and ring nematode resistance (Burton, 1991; Hanna et al., 1990). Although it was coarser and did not tolerate wear traffic 
as well as 'Tifway', its aggressive growth habit and low maintenance requirements allowed for its eventual release as 'Tifton 10' in 1988 (Hanna et al., 1990).

\section{Protecting the Future of Turfgrass Breeding}

Despite the many successful bermudagrass cultivar releases, there were several problems facing the future of turf bermudagrass in the 1990s. First, golfers demanded improved putting green quality compared with that provided by creeping bentgrass (Agrostis stolonifera L.) found in the northeastern United States (Hanna, 1996). The existing releases could not withstand the low mowing heights required to achieve a comparable putting surface without losing stand density and quality. Second, there was a lack of reliable planting stock because of unplanned mutations and contamination in nursery fields. Finally, susceptibility to pests was a major concern, as there were largely only two cultivars being utilized throughout the southeastern United States. There was a clear need for genetically different cultivars that could maintain quality and persistence at mowing heights less than $4 \mathrm{~mm}$.

Therefore, the next goal of the Tifton Turfgrass Breeding Program was to develop dwarf cultivars with more stringent standards for certification (Hanna, 1996). Researchers again decided to induce mutations into established cultivars using cobalt-60 gammaradiation to increase genetic diversity while reducing the time required for the next cultivar release. Tift 94 and TW-72 were, respectively, released in 1995 and 1997 and were correspondingly named 'TifSport' and 'TifEagle' (Hanna et al., 1997; Hanna and Elsner, 1999). These were the first hybrid bermudagrasses to be patented from Tifton. Both cultivars were selected for persistence under close mowing and lower levels of tawny mole cricket (Scapteriscus victims Scudder) infestation compared with the previously superior 'Tifway' and 'Tifdwarf' (Hanna et al., 1997; Hanna and Elsner,
1999). 'TifSport' had greater canopy density than 'Tifway' and exhibited increased cold tolerance, allowing it to be planted farther north (Hanna et al., 1997). 'TifEagle' resulted in a better putting surface, as it had fewer seedheads and produced more stolons and shorter, narrower leaves than 'Tifdwarf' (Hanna and Elsner, 1999).

After these two releases, focus was put on improving the shade tolerance of bermudagrass for lawns, golf courses, and other landscapes where light may be reduced. Six C. transvaalensis genotypes were selected for their persistence under low management and crossed with six $C$. dactylon cultivars known for their cold tolerance or persistence under close mowing during 1992 (Hanna et al., 2010). Beginning in 1999, 60 of the resulting hybrids were selected under continuous shade conditions where light was always reduced by at least $60 \%$ of photosynthetically active radiation. A naturally darker green, dwarf-type genotype was discovered that maintained quality under shade and was released as ST-5 in 2009 and commercially named 'TifGrand'.

\section{Innovation for the Future: Drought Tolerance}

Today, the goal of the Tifton Turfgrass Breeding Program is to develop cultivars that are adapted to a broader range of environments and have improved drought tolerance. The latter is particularly important, as irrigation restrictions during drought events are becoming more common. The latest commercial turfgrass release is 'DT-1', an interspecific hybrid triploid $(2 n=3 x=27)$, that was evaluated in 19 drought-stress trials throughout the United States before it was commercially released. 'DT-1' can better withstand drought and traffic than previous commercial releases. In addition, it was generally faster growing than other bermudagrass cultivars and maintained turfgrass cover and green color longer each fall. 'DT1 ' was co-released by the University of Georgia and the USDA-ARS in 2014 after more than 20 years of evaluations and commercially named 'TifTuf'.

For additional information about the Tifton Turfgrass Breeding Program or any of the commercial releases, please visit http:// georgiacultivars.com/cultivars/turfgrass.

\section{Literature Cited}

Burton, G.W. 1955. Better turfgrasses can be produced by breeding. USGA J. Turf Mgt. 8:2829.

Burton, G.W. 1964. Tifgreen (Tifton 328) bermudagrass for golf greens. USGA Green Sect. Rec. 2:11-12.

Burton, G.W. 1966a. Tifway (Tifton 419) bermudagrass. Crop Sci. 6:93-94.

Burton, G.W. 1966b. Tifdwarf bermudagrass. Crop Sci. 6:94

Burton, G.W. 1981. Tifway II bermudagrass released. USGA Green Sect. Rec. 19:8.

Burton, G.W. 1991. A history of turf research at Tifton. USGA Green Sect. Rec. 29:12-14.

Hanna, W.W. 1996. TW-72: A potential new bermudagrass for golf greens. USGA Green Sect. Rec. 34:11-12.

Hanna, W.W. and J.E. Elsner. 1999. Registration of 'TifEagle' bermudagrass. Crop Sci. 39:1258.

Hanna, W.W., G.W. Burton, and A.W. Johnson. 1990. Registration of 'Tifton 10' turf bermudagrass. Crop Sci. 30:1355-1356

Hanna, W., P. Raymer, and B. Schwartz. 2013. Warm-season grasses: Biology and breeding, $\mathrm{p}$. 543-590. In: J.C. Stier, B.P. Horgan, and S.A. Bonos (eds.). Turfgrass: Biology, use, and management, Agronomy Monograph No. 56. American Society of Agronomy, Madison, WI.

Hanna, W.W., R.N. Carrow, and A.J. Powell. 1997. Registration of 'Tift 94' bermudagrass. Crop Sci. 37:1012.

Hanna, W.W., S.K. Braman, and B.M. Schwartz. 2010. 'ST-5', a shade-tolerant turf bermudagrass. HortScience 45:132-134.

Hein, M.A. 1953. Registration of varieties and strains of bermudagrass, II. (Cynodon dactylon (L.) Pers.). Agron. J. 45:572-573.

Hein, M.A. 1961. Registration of varieties and strains of bermudagrass, III. (Cynodon dactylon (L.) Pers.). Agron. J. 53:276.

Robinson, B.P. and G.W. Burton. 1953. Tiffine (Tifton 127) turf bermudagrass. USGA J. Turf Mgt. 6:30. 